\title{
Polish suture zone as the goblet of truth in post-glacial history of mammals in Europe
}

\author{
Joanna Stojak $^{1}$ (D) Ewa Tarnowska ${ }^{1}$ \\ Received: 27 February 2019 / Accepted: 8 May 2019 / Published online: 21 May 2019 \\ (C) The Author(s) 2019, corrected publication 2019
}

\begin{abstract}
Present-day species distribution and patterns of genetic diversity in Europe are a result of post-glacial re-colonization from glacial refugia after the Last Glacial Maximum. This process led to the formation of secondary contact zones (suture zones) between the haplogroups of different species, and were induced by several factors, including climate and evolutionary processes like selection and adaptation. One such suture zone has been found in Poland, where a complex network of different phylogenetic lineages of predators, ungulates, and rodents is present. The phylogeography of mammals in western Europe has been widely studied, but central and eastern Europe have been treated cursorily. Only a few samples from these areas were analyzed in previous studies, resulting in a simplified and false description of local genetic structure. In this review, results of previous phylogeographic studies on carnivore, ungulate, and rodent species from central and eastern Europe were collected and synthesized to verify the Polish suture zone hypothesis and examine how it is affected by different variables (geomorphological features like the Carpathian Mountains and Vistula River, climate, or anthropogenic factors). Our data reflects the importance of precise studies in this region and the value they contribute to further studies of large-scale European phylogeography.
\end{abstract}

Keywords Contact zone $\cdot$ Genetic diversity $\cdot$ Last Glacial Maximum $\cdot$ Phylogeography $\cdot$ Glacial refugia $\cdot$ Climatic factors

\section{Introduction}

During the last glaciation (Weichselian; $115 \pm 11.5$ thousand years ago, kya) (Rasmussen et al. 2014), the Scandinavian ice sheet advanced and retreated multiple times, and different fauna and flora species survived unfavorable conditions in glacial refugia (Hewitt 1999; Avise 2000, 2004; Stewart and Lister 2001; Sommer and Nadachowski 2006). The coldest conditions and maximum extent of the Scandinavian ice sheet were present during the Last Glacial Maximum (LGM; 27.5 to 19 kya; Clark et al. 2009; Hughes et al. 2013; Alvarado et al. 2011), when ice sheets covered the entirety of Scandinavia as well as huge areas in the British Isles, Germany, Poland, and northern parts of the East European Plain (northern Russia). Meanwhile, periglacial areas were covered by an

Communicated by: Jeremy Herman

Joanna Stojak

jstojak@ibs.bialowieza.pl

1 Mammal Research Institute Polish Academy of Sciences, ul. Stoczek 1, 17-230, Białowieża, Poland
Arctic tundra (Lozinski 1909; Tarasov et al. 2001; Cheddadi and Bar-Hen 2008; Strandberg et al. 2011).

Present-day species distribution in Europe is a result of rapid climate warming after the LGM that induced abrupt post-glacial re-colonization from glacial refugia (Hewitt 1999; Stewart and Lister 2001; Sommer and Nadachowski 2006; Pazonyi 2004; Stewart et al. 2010; Tzedakis et al. 2013; Baca et al. 2017; Quinzin et al. 2017). Since various genetic changes have been retained in organisms that survived in glacial refugia, separate phylogenetic lineages (haplogroups), that reveal the evolutionary history of a species, can be identified (Hewitt 1999; Taberlet et al. 1998; Avise 2000, 2004; Michaux et al. 2003). Therefore, the phylogeography of different mammalian, reptilian, avian, and plant species unravels the post-glacial history of the whole continent (e.g., Davison et al. 2001; Tarasov et al. 2001; Palmé et al. 2003; Kvist et al. 2004; Colangelo et al. 2010; Dool et al. 2013; Montgomery et al. 2014; Herrera 2017; Wielstra et al. 2017; Horreo et al. 2018). Previous studies have shown that species range is determined by multiple factors, such as topographic barriers (e.g., mountain chains, seas, large rivers; Cox and Moore 1993; Tougard et al. 2013; Herrera 2017; Murphy et al. 2017) or specific adaptations to climatic, environmental, 
and biotic conditions (e.g., competition, predation, food availability; Warren etal. 2000; Dingerkus and Montgomery 2001).

Over the last few decades, numerous phylogeographic studies concerning mammalian species have been conducted in western Europe using different molecular markers - short tandem repeats (STR, microsatellite DNA; e.g., Neumann et al. 2005; Beysard and Heckel 2014; Herman et al. 2019), single nucleotide polymorphisms (SNP; e.g., Kotlík et al. 2018), the Y chromosome (e.g., Herman et al. 2019; Jones and Searle 2015), and different fragments of mitochondrial DNA (mtDNA), such as the control region (D-loop) or cytochrome $b$ gene (e.g., Haynes et al. 2003; Deffontaine et al. 2005; Heckel et al. 2005; Neumann et al. 2005; Saarma et al. 2007; Braaker and Heckel 2009; Searle et al. 2009; Skog et al. 2009; Lebarbenchon et al. 2010; Edwards et al. 2012; Herman et al. 2014; Martínkovà et al. 2013; Kinoshita et al. 2017; Herman et al. 2019). However, only results from studies using maternally inherited mtDNA are accessible (for instance, in GenBank database) and useful for continental comparison. Therefore, we recognize this marker as the most fundamental and commonly used tool in large-scale phylogeography.

In Europe, phylogeography and phylogenetic patterns have contributed to the identification of contact zones between the haplogroups of one species, and even between multiple genetic lineages of different species. This complex co-occurrence of contact zones is known as a "suture zone," and is maintained by many factors, including climate, selection, and adaptation (Hewitt 1999; Remington 1968). In western Europe, six suture zones have been identified and well-described (Hewitt 1999; Schmitt 2007). Although Remington (1968) suggested that other suture zones could be found in the Ural and central Europe, for a long time, these regions have been treated cursorily and omitted in phylogeographic studies. Moreover, high inaccessibility of data from eastern Europe (such as from the Russian Federation, Belarus, or Ukraine) is also a challenge, as data is frequently published only in Russian, or translated into English with a delay (Pavlov 1999; Abramson et al. 2009; Bulatova et al. 2010; Zhigileva and Gorbacheva 2017; Sibiryakov et al. 2018).

In multiple previous phylogeographic studies, only a few samples from central or eastern Europe have been analyzed, which has resulted in a simplified and incorrect description of genetic structure in this area (e.g., Randi et al. 2004; Deffontaine et al. 2005; Heckel et al. 2005; Neumann et al. 2005; Skog et al. 2009; Meiri et al. 2013). For instance, based on four samples of the common vole (Microtus arvalis) from one location in north-eastern Poland, Haynes et al. (2003) hypothesized that only one phylogenetic lineage is present in central Europe. However, further studies have revealed a more complex pattern of genetic diversity within this species in this area (Stojak et al. 2015, 2016a). Similar findings were detected in the cases of other mammalian species in central Europe. As a result, Wójcik et al. (2010) suggested the presence of a suture zone between species, races, and genetic lineages in Poland, which was consistent with Remington's (1968) predictions.

In Poland, a strong East-West precipitation gradient, resulting from the collision of wet Atlantic air in the West and dry continental air in the East is present (Starkel 1991; Hijmans et al. 2005; Stojak et al. 2019). During the LGM, Poland was covered by ice in the North and tundra in the South (Wysota et al. 2002, 2009; Marks et al. 2016), in close proximity to the Carpathian Basin - a well-known temperate refugial area (Sommer and Nadachowski 2006; Pazonyi 2004; Tzedakis et al. 2013). Moreover, because it is located in the center of Europe, Poland could be part of natural migration corridor for many fauna and flora species, even from Asia (Trojan 1997).

The main aim of this article was to collect and combine results of previous phylogeographic studies on different mammal species from central and eastern Europe and verify the existence of a suture zone in Poland or central Europe (Wójcik et al. 2010). Such a summary will contribute a comprehensive description of post-glacial re-colonization scenarios of Polish territory by different species of carnivores, ungulates, and rodents. Furthermore, this review also examines the influence of different variables (geomorphological features like the Carpathian Mountains and Vistula River, climate, or anthropogenic factors) on contemporary genetic diversity of mammalian communities and the maintenance of a suture zone in Poland. Ultimately, we assume that the aforementioned combined data from central and eastern Europe highlights the importance of this region in precise studies of large-scale European phylogeography.

\section{Characteristics of a suture zone in Poland}

The Polish suture zone is a very wide and complex formation, consisting of multiple contact zones between different haplogroups of at least 11 species of large carnivores, ungulates, and small mammals (Fig.1, Table 1).

\section{Apex predators}

Two apex predators should be taken into consideration when describing the post-glacial re-colonization of Poland: the Eurasian lynx (Lynx lynx) and the gray wolf (Canis lupus).

There are three groups of lynx present in Poland, although high levels of habitat fragmentation prevent their secondary contact (Fig. 1a, Table 1). The Carpathian population is distinct from the north-eastern one, which is differentiated in two groups (Ratkiewicz et al. 2012, 2014). The BPF group, found only in Białowieża Primeval Forest, is characterized by low genetic variability. On the other hand, the neighboring KARPF group encompasses lynx found in Lithuania, Latvia, Estonia, Finland, and Russia (Ratkiewicz et al. 2014). Observed patterns of genetic diversity suggest that lynx 
expanded from the Carpathian refugium following the LGM, while the formation of the two northern groups can be attributed to post-glacial re-colonization processes (Ratkiewicz et al. 2014).

In the case of the gray wolf, Pilot et al. (2010) identified a wide contact zone between two haplogroups of this species in southern Poland (Fig. 1a, Table 1). Haplogroup 1, which likely originated from the Apennine Peninsula, was found in Carpathian populations (Pilot et al. 2010). In Poland, haplogroup 2, fixed in the Iberian Peninsula, differentiated into three subpopulations: one found only in south-eastern Poland, a second (and the most abundant) found mainly in western and northern Poland, and a third found in northeastern Poland (Czarnomska et al. 2013).

\section{Ungulates}

Three large herbivorous species (European roe deer Capreolus capreolus, red deer Cervus elaphus, and European moose Alces alces) can be found in the Polish suture zone.

Three mtDNA lineages of European roe deer meet in south-eastern Poland and are referred to as the Central, West, and East clades (Fig. 1b, Table 1; Matosiuk et al. 2014a; Olano-Marin et al. 2014). The Central and West haplogroups probably originated from the Iberian refugium, while the East clade survived the last glaciation on the Balkan Peninsula (Randi et al. 2004). Moreover, Matosiuk et al. (2014a, b) described a very wide contact zone between European and Siberian roe deer (C. pygargus) in the eastern part of Poland.

A similar phylogeographic pattern was found in red deer, a species that survived the last glaciation in western refugia located on the Iberian Peninsula and eastern refugia in the Balkans (Fig. 1b, Table 1; Skog et al. 2009). Two haplogroups (A and $\mathrm{C}$ ), reflecting the aforementioned evolutionary history of $C$. elaphus, have been found in Poland, with a contact zone in the central part of the country (Niedziałkowska et al. 2011). Fossil records indicate that red deer were also present in the Carpathian Basin during the Last Glacial Maximum (Sommer and Nadachowski 2006).

In the case of European moose, a contact zone between three haplogroups was identified in central Poland (Fig. 1b, Table 1). The Eastern clade likely re-colonized Europe from refugia located in the Ukraine or Russian Plains, while the Western lineage is thought to have originated from France or Belgium. The Central haplogroup, on the other hand, is believed to have survived the last glaciation in the Carpathian or Balkan refugia (Niedziałkowska et al. 2014).

\section{Small mammals}

Polish communities of small mammals probably arose towards the end of the Pleistocene (Nadachowski 1989). Their evolutionary history and routes of post-glacial colonization have been reconstructed on the basis of fossil records, which are important indicators of glacial refugia. Nonetheless, wellpreserved skeletons of small mammals were found only in a few locations in southern Poland (Nadachowski 1990; Nadachowski et al. 2009), so genetic markers have instead been used to provide new insight into post-glacial history at a larger scale. Until now, multiple studies on the phylogeography of small mammals, primarily rodents, have been conducted in Poland.

One of these rodents, the common hamster (Cricetus cricetus) is considered a critically endangered species. Genetic studies on small Polish populations have revealed a contact zone between two haplogroups of this species in the Małopolska Upland (southern Poland; Fig. 1d, Table 1; Banaszek et al. 2012). Of these, the Pannonian lineage probably originated from the Carpathian refugium, while the E1 lineage originated from the Russian Plains or Ukrainian steppe (Banaszek et al. 2012).

Another rodent that survived the LGM in the Carpathian refugium is a woodland species, the bank vole (Clethrionomys glareolus; Kotlík et al. 2006). In Poland, three mtDNA lineages have been described and named according to their refugial origin: the Carpathian, Western, and Eastern (Fig. 1d, Table 1; Wójcik et al. 2010). The contact zone between the Carpathian and Eastern lineages is very wide and spread across Poland, from the north-eastern to the south-western part of the country (Wójcik et al. 2010; Tarnowska et al. 2016, 2018). Individuals from the Western clade were found in only a few regions in southern and central Poland (Wójcik et al. 2010; Tarnowska et al. 2016).

A small predator, the weasel (Mustela nivalis), has four haplogroups in Poland (McDevitt et al. 2012). A contact zone between the Carpathian, Western, and Eastern lineages is located in the central part of the country (Fig. 1c, Table 1; McDevitt et al. 2012). In central and southern Poland, a few individuals belonging to the Balkan clade have also been identified (McDevitt et al. 2012).

The European pine marten (Martes martes) presents another example of a small predator's contact zone. Ruiz-González et al. (2013) discovered two phylogenetic lineages of this species in north-eastern Poland: the central-northern European and Mediterranean lineages (Fig. 1c, Table 1).

Phylogeographic patterns have also been studied for two sibling species, the common vole (Microtus arvalis) and the field vole (Microtus agrestis). These two rodent species are morphologically very similar, but they differ in habitat preferences. The common vole survived the last glaciation in both southern and northern refugia. A contact zone between two haplogroups of this species is located in north-western Poland: the Eastern lineage probably originated in the Carpathian refugium and the Central lineage is thought to have originated in the Alps (Fig. 1d, Table 1; Stojak et al. 2015, 2016a). The field vole, on the other hand, re-colonized central Europe from 
exclusively southern refugia (Jaarola and Searle 2002; Herman and Searle 2011). In south-western Poland, two mtDNA lineages of this rodent have been found and referred to as the Western and Central-European clades (Fig. 1d, Table 1; Herman et al. 2014).

\section{Factors maintaining the Polish suture zone}

The maintenance of a suture zone is a dynamic and multilateral process. In this article, we assume that Polish suture zone formation is the result of post-glacial re-colonization processes from glacial refugia and subsequent adaptations to environmental and climatic conditions. Therefore, in this chapter, we analyze the possible influence of the Carpathians, large river corridors, climate, and human impact on the emergence and maintenance of the Polish suture zone. To fulfill our objective, we compiled and synthesized evidence from the aforementioned phylogeographic studies on various mammalian species found in central Europe.

\section{Carpathian Mountains}

The Carpathian Mountains are the largest mountain range in central Europe. During the last glaciation, only high mountain peaks in the Tatra Mountains were covered with ice and snow (Zasadni and Kłapyta 2014), their surroundings were covered by an Arctic tundra (Pazonyi 2004; Sommer and Nadachowski 2006). Fossil records and genetic studies have confirmed the location of a glacial refugium in the Pannonian Basin (Pazonyi 2004), as well as the presence of diversified mammal communities on the northern slopes of the Carpathian Mountains (such as in the Orawa-Nowy Targ Basin, at Obłazowa cave and Obłazowa 2 paleontological sites), during and just after the LGM (Valde-Nowak et al. 2003; Nadachowski et al. 1993; Nadachowski and Valde-Nowak 2015). Records of areas that were once rich in small mammals date back to approximately 25-15 calibrated kya and support the presence of a diverse fauna even within the Tatra Mountains (Horáček et al. 2015).

During the LGM, many different mammals were present in the Carpathian refugium, including red foxes (Vulpes vulpes), brown bears (Ursus arctos), red and roe deer, moose, European pine marten, hedgehogs (Erinaceus sp.), and bank voles (Stewart and Lister 2001; Pazonyi 2004; Kotlík et al. 2006; Sommer and Nadachowski 2006). The geographic location and size of the Carpathian Mountains made this area a well-preserved environment and biodiversity hot spot for many organisms, not only mammals.

Ratkiewicz et al. (2014) showed that the entire contemporary lynx population in central Europe and Scandinavia originated from the Carpathians. According to genetic studies, lynx belonging to BFP and KARPF populations separated
Fig. 1 The suture zone in Poland (central Europe) consists of multiple contact zones between different haplogroups of (a) carnivores: -Eurasian lynx (Ll) and gray wolf $(\mathrm{Cl})$; (b) ungulates -roe deer $(\mathrm{Cc})$, red deer $(\mathrm{Ce})$, and European moose (Aa); (c) small predators-weasel (Mn) and pine marten (Mm); and (d) rodents-common hamster (Ccri), bank vole (Cg), common vole (Ma), and field vole (Mag). The Vistula River (blue solid line), as well as the Sudetes and Carpathian Mountains (gray area) are marked on the map of Poland

from the Carpathian group, and subsequent separations from the BFP and KARPF groups resulted in the formation of separate lynx populations in Russia and Finland, and eventually in Norway.

High mobility of large predators and ungulates allows them to cross mountain ranges or use them as suitable habitats. Nonetheless, the likelihood of mountains acting as a barrier to gene flow varies across species. Pilot et al. (2006) detected no physical barriers to dispersal for wolves in central and eastern Europe, while Niedziałkowska et al. (2016) suggested that high mountain ranges could be a barrier to gene flow in moose populations.

In the case of small mammals, the Carpathians could be a significant geographic barrier, both for migration and gene flow. The Pannonian lineage of the common hamster, which survived the LGM in the Carpathian refugium, re-colonized Poland only through the Moravian Gate, a natural depression between the Carpathian Mountains in the East and the Sudetes in the West (Banaszek et al. 2012). On the other hand, the Balkan lineage of the weasel probably reached Poland through the Carpathian mountain range, though details of this recolonization are still unknown (McDevitt et al. 2012).

Ultimately, the Carpathian Mountains have significantly influenced - both positively and negatively - the contemporary structure of the Polish suture zone, having acted as both a refugial area for many temperate species and a barrier preventing certain lineages from reaching Polish territory (Table 1).

\section{Vistula river}

The Vistula is both the longest and largest river in Poland and one of the longest rivers in Europe. The last glaciation, lasting until 11.7 thousand years ago (kya), was named the Weichselian (Vistulian) glaciation, after this river. During the LGM, the Scandinavian ice sheet covered large areas from the Pskov region in Russia to Denmark, reaching through central Poland (Wysota et al. 2002, 2009; Stroeven et al. 2016). As a result, the Vistula corridor was very broad and covered by permafrost patches (Starkel 1991, 2001; Stojak et al. 2016a). After the Younger Dryas (approximately 11 kya), when the climate rapidly warmed, the ice sheet and permafrost patches on the river melted intensively, causing flooding over a large area. The middle Vistula valley eventually consisted of sand dunes with strong winds that re-shaped 


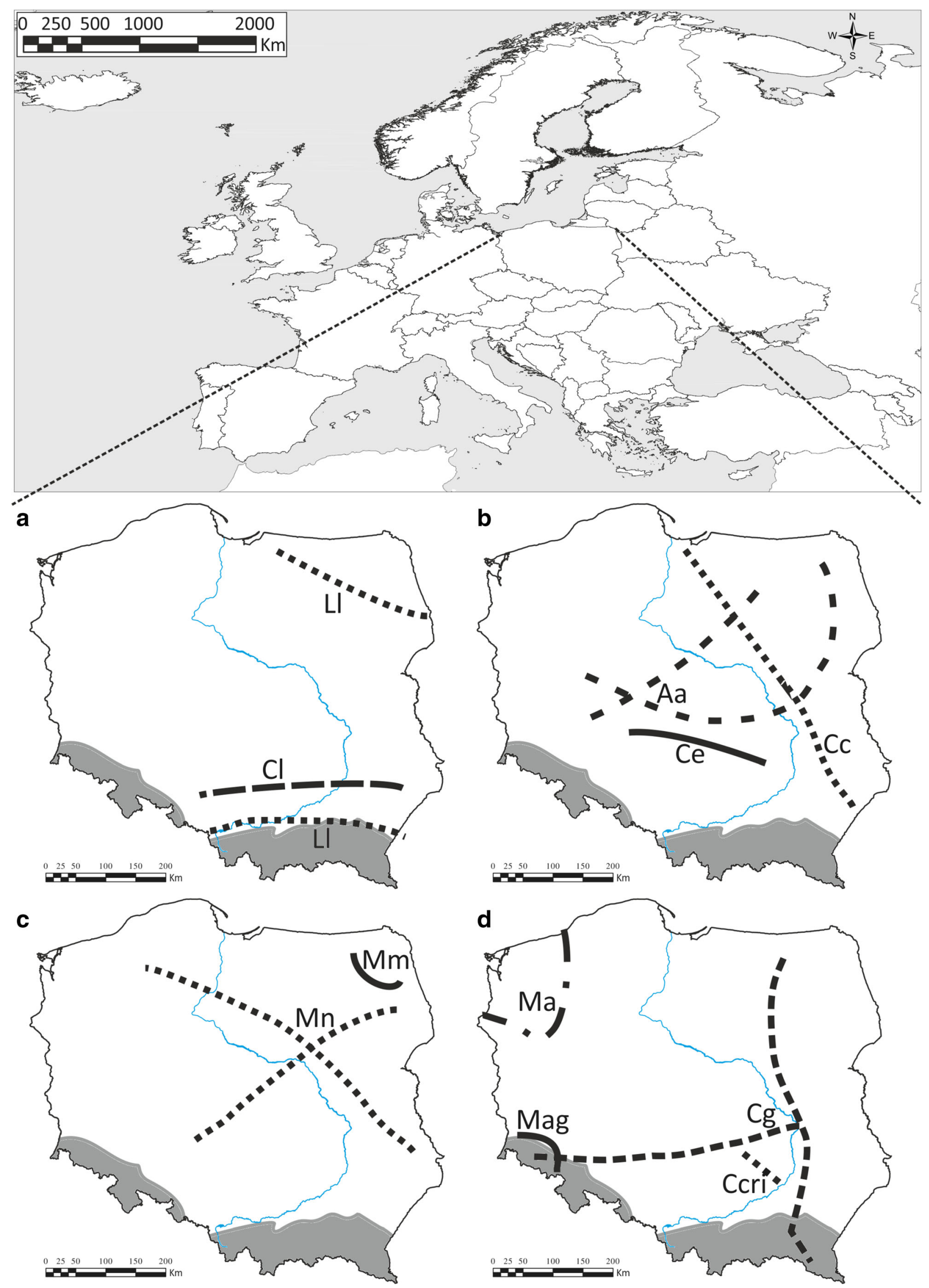




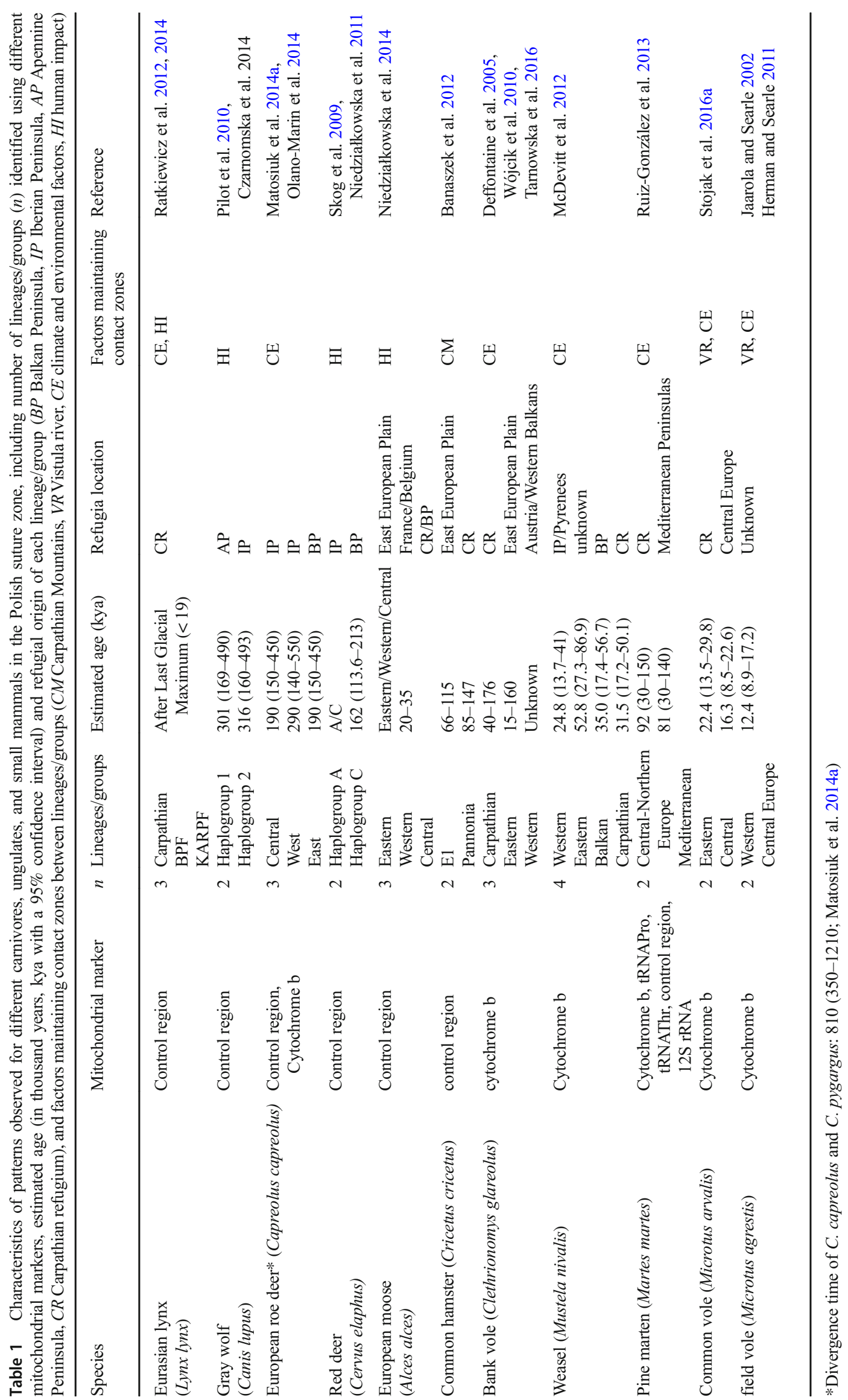


it continuously (Starkel 1991, 2001). All of these processes led to the Vistula river acting as a geographic barrier to gene flow for populations of small mammals (Stojak et al. 2016ab). The dynamic processes lasted until 8-9 thousand years ago, when the Vistula corridor consequently started to stabilize (Starkel 1991).

Niedziałkowska et al. (2016) suggested that large areas of water, such as wide river corridors, could be a barrier to migration and gene flow even for swimmers as good as moose. Matosiuk et al. (2014a) revealed that the location of the Vistula river could have had a significant effect on the maintenance of Siberian roe deer mtDNA in the European roe deer genome.

Nevertheless, contemporary genetic structure of small mammal communities in Poland showed no strong evidence that the Vistula could be an important barrier to gene flow. Studies on the contact zone between two haplogroups of the bank vole in north-eastern Poland reported unlimited exchange of genetic information (both mitochondrial and nuclear) between populations located on opposite banks of the river (Tarnowska et al. 2016, 2018). On the other hand, the genetic structures of the common and field voles suggested that the major Polish river delayed gene flow between populations, and that this eventual exchange occurred only in the valley of the lower Vistula (northern Poland; Stojak et al. 2016b, 2019).

Despite their size and physical limitations, small mammals are able to cross long distances and potential geographic barriers with the - usually unintentional - help of humans. Martínková et al. (2013) showed that approximately 5000 years ago, several individuals of the common vole from Belgium were transported by the Neolithic people to the Orkney archipelago, situated off the north coast of Great Britain. Therefore, further studies are needed to more precisely describe the influence and role of the Vistula river in Polish suture zone formation and maintenance (Table 1).

\section{Climate and environmental conditions}

The western part of Poland is characterized by a warmer and more humid climate than is found in the eastern part of the country. This has led to contact between different genetic groups that are adapted to variable climatic and environmental conditions.

Ratkiewicz et al. (2014) suggested that latitude and depth of snow cover could have a significant effect on the observed genetic structure of lynx populations. The complex distributions of the Siberian and European roe deer in Poland (including the contact zone between three haplogroups of C. capreolus) are significantly influenced by the number of days that exhibit snow cover, subsequent snow depth, average temperature during the month of January, and the number of days that temperatures fall below freezing throughout the whole year (Matosiuk et al. 2014a).
Pilot et al. (2006) suggested that the genetic differentiation observed among populations of wolves in central Europe could be a result of climate, habitat availability, and habitat conditions influencing the carnivore's diet. Gula (2004) noticed that snow cover had an effect on predation by wolves, and concluded that predator-prey interactions play an important role in the formation of contemporary patterns in mammal species distribution across Europe.

An even stronger influence of climate was recorded in small mammal populations. Tarnowska et al. (2016) revealed that the occurrence of the Carpathian lineage of bank voles in north-eastern Poland was positively correlated with mean temperature in July and the distribution of plant species associated with the Carpathian refugium. In the case of two sibling species, the common and field voles, average minimum temperature in January most influenced the genetic structure of these rodents in Poland. Additionally, average annual precipitation was also an important factor for the field vole, a species that prefers wet and humid environments (Stojak et al. 2019). These results are in agreement with adaptations observed in Polish populations of weasel, a predator of the voles. According to the description of McDevitt et al. (2012), the distribution of $M$. nivalis haplogroups significantly depended on the number of days with snow cover throughout the year, as well as the average minimum temperature in January. In general, the Carpathian lineage of weasels was reported to be more adapted to a cold, severe climate than the Balkan lineage.

Climate, environmental conditions, and availability of preferred habitats are crucial factors influencing the distribution of species, lineages, and genetic groups. We predict that lineages fixed in the Carpathian refugium could be more resistant to cold climate than lineages that originated in southern refugia; therefore, climate is likely the leading factor involved in the shaping and maintenance of suture zones in Europe (Table 1).

\section{Human impact}

Human activity has a great impact on the biodiversity and genetic structure of species, lineages, and populations worldwide. Excessive hunting and the fragmentation of natural habitats have resulted in the extirpation or endangerment of many species, including the Eurasian lynx and gray wolf (Huck et al. 2010). The Eurasian lynx was once cosmopolitan across Europe, but in the nineteenth century, it was extirpated in the western and central parts of the continent. Nowadays, in central Europe, the species inhabits only the Carpathian Mountains and edges of north-eastern Poland (Ratkiewicz et al. 2012, 2014), as populations are threatened by habitat loss, poaching, and diminution of prey (Schmidt 2008; Schmidt et al. 2011). A similar situation has been observed in the gray wolf (Jędrzejewska et al. 1996; Gula 2008). 
Ungulate populations, on the other hand, have experienced profound growth following a decrease in the number of apex predators (Jędrzejewski et al. 2012).

During the early twentieth century, all ungulate species described in this article underwent population number declines and changes in their distribution in Poland, mainly due to deforestation and overhunting. Therefore, the contemporary genetic structure of roe deer, red deer and moose is largely the result of introductions and translocations of individuals between populations (Skog et al. 2009; Matosiuk et al. 2014a, b; Świsłocka et al. 2013). Present-day forest management and low pressure from predators, however, have facilitated rather abrupt and unusual range expansions for each of these ungulate species (Jedrzejewski et al. 2012; Matosiuk et al. 2014a).

The contact zone between European and Siberian roe deer in eastern Poland is a result of the introduction of C. pygargus to two locations: the Białowieża Primeval Forest in 1891 (Pavlov 1999) and Silesia in 1909 (Gleiss 1967). In the case of red deer, while the distribution of the Eastern haplogroup is a result of post-glacial re-colonization, the pattern observed for the western clade seems to be artificial and shaped by the reintroduction of this species to areas where it was previously extirpated (Niedziałkowska et al. 2011, 2012). Likewise, after the Second World War, moose came close to extinction, and only a few isolated populations from north-eastern Poland, East Prussia, and Sweden survived throughout central Europe (Gębczyńska and Raczyński 2004; Schmölcke and Zachos 2005; Charlier et al. 2008; Steinbach 2009; Świsłocka et al. 2013). In Poland, the relict population, found in the Biebrza marshes, is characterized by the presence of a unique H1 haplotype (Świsłocka et al. 2008, 2013).

Humans can also influence the genetic structure of small mammals - a phenomenon that has been already presented in this article with the example of common vole populations introduced to the Orkney Islands by the Neolithic people (Martínkovà et al. 2013). In Poland, however, there is no evidence that anthropogenic factors have shaped the distribution of haplogroups in bank vole, weasel, common vole, or field vole populations. Nevertheless, contemporary agriculture, cultivation of monocultures, and use of pesticides could have played a role in changes to small mammal distributions. For instance, the population of yellow-necked mice (Apodemus flavicollis) is growing rapidly throughout the country, to the point that the rodent can now be found in many different habitats, including human houses. This leads to the displacement of other species, such as voles, and ultimately a decrease in their numbers (Authors' personal observations, not published).

The reviewed studies suggest that anthropogenic factors could play an important role in shaping genetic structure, and should thus also be considered indirect elements in suture zone formation and maintenance (Table 1).

\section{Conclusions}

In Poland, a complex network of contact zones between different phylogenetic lineages of carnivores, ungulates, and rodents is present. However, there are also species for which no genetic structure has been found in this area. For instance, the brown bear (Ursus arctos; Davison et al. 2011; Bray et al. 2013), the European badger (Meles meles; Frantz et al. 2014), and the common shrew (Sorex araneus; Raspopova et al. 2018), each have only a single mtDNA lineage in Poland. Meanwhile, the most recent phylogeographic analyses of the wild boar (Sus scrofa) in Poland identified one haplogroup E1, with variation between two subgroups, E1a and E1c (Alexandri et al. 2012; Kusza et al. 2014; Vilaça et al. 2014). However, in the case of the boar, genetic structure has changed drastically in response to both intense harvesting and population reduction because of African swine fever (ASF) outbreaks in central and eastern Europe (Podgórski et al. 2018; Podgórski and Śmietanka 2018).

We assume that all phylogeographic studies on the different mammalian carnivore, ungulate, and rodent species presented in this review have provided indirect evidence supporting the Polish suture zone hypothesis (Remington 1968; Wójcik et al. 2010). Analyses using different molecular markers (mtDNA, microsatellite DNA) have shown that central Europe is a very dynamic and diverse study area in terms of genetic variation. The mammal species included in this article each have unique evolutionary histories and routes of post-glacial re-colonization throughout central and eastern Europe. Nevertheless, further studies regarding phylogeography and genetic diversity in this region are needed, complemented by the analysis of ancient DNA extracted from fossils (Davison et al. 2011; Edwards et al. 2012; Bray et al. 2013; Lagerholm et al. 2014) and identification of genes responsible for specific adaptations (Filipi et al. 2015).

This review demonstrates that the formation and maintenance of suture zones in central Europe is a complex process, influenced by factors such as geographic barriers, climate, and environmental conditions. These elements may not be as influential when considered separately, but they create an interesting mosaic of cause and effect when viewed holistically. As a result, any hypotheses concerning European phylogeography should not be based on narrow spatial scales, small sample sizes, or the extrapolation of results from studies conducted in adjacent areas. Preventing erroneous conclusions, avoiding incomplete interpretations of large-scale patterns of genetic diversity, and uncovering the truth of European post-glacial history are challenging tasks, but crucial for applying phylogenetic patterns to conservation genetics and ultimately the protection of endangered species and disappearing habitats. 
Acknowledgments The authors thank the anonymous reviewers for their helpful comments that significantly helped improve this manuscript. We also thank A. Michalak (Cornell University) for English language editing.

Data accessibility This article has no additional data.

Authors' contribution J.S. and E.T. participated in conceptualizing and writing the manuscript. Both authors approved the final version of the manuscript and agree to be held accountable for the content therein.

\section{Compliance with ethical standards}

Competing interests The authors declare that they have no competing interests.

Open Access This article is distributed under the terms of the Creative Commons Attribution 4.0 International License (http:// creativecommons.org/licenses/by/4.0/), which permits unrestricted use, distribution, and reproduction in any medium, provided you give appropriate credit to the original author(s) and the source, provide a link to the Creative Commons license, and indicate if changes were made.

\section{References}

Abramson NI, Rodchenkova EN, Kostygov AY (2009) Genetic variation and phylogeography of the bank vole (Clethrionomys glareolus, Arvicolinae, Rodentia) in Russia with special reference to the introgression of the mtDNA of a closely related species, red-backed vole (Cl. rutilus). Russ J Genet 45:533-545. Original Russian Text: Abramson NI, Rodchenkova EN, Kostygov AY (2009) Genetika 45: 610-623. https://doi.org/10.1134/S1022795409050044

Alexandri P, Triantafyllidis A, Papakostas S, Chatzinikos E, Platis P, Papageorgiou N, Larson G, Abatzopoulos TJ, Triantaphyllidis C (2012) The Balkans and the colonization of Europe: the postglacial range expansion of the wild boar, Sus scrofa. J Biogeogr 39:713-723. https://doi.org/10.1111/j.1365-2699.2011.02636.x

Alvarado CJA, Leuenberger M, Kipfer R, Paces T, Purtschert R (2011) Reconstruction of past climate conditions over central Europe from groundwater data. Quat Sci Rev 30:3423-3429. https://doi.org/10. 1016/j.quascirev.2011.09.003

Avise JC (2000) Phylogeography: the history and formation of species. Harvard University Press, Cambridge

Avise JC (2004) Molecular markers, natural history, and evolution, 2nd edn. Sinauer Associates, Sunderland, Massachusetts

Baca M, Nadachowski A, Lipecki G, Mackiewicz P, Marciszak A, Popović D, Socha P, Stefaniak K, Wojtal P (2017) Impact of climatic changes in the Late Pleistocene on migrations and extinctions of mammals in Europe: four case studies. Geol Quart 61(2):291-304. https://doi.org/10.7306/gq.1319

Banaszek A, Ziomek J, Jadwiszczak KA, Kaczyńska E, Mirski P (2012) Identification of the barrier to gene flow between phylogeographic lineages of the common hamster. Acta Theriol 57:159-204. https:// doi.org/10.1007/s13364-012-0075-Z

Beysard M, Heckel G (2014) Structure and dynamics of hybrid zones at different stages of speciation in the common vole (Microtus arvalis). Mol Ecol 23:673-687. https://doi.org/10.1111/mec.12613

Braaker S, Heckel G (2009) Transalpine colonisation and partial phylogeographic erosion by dispersal in the common vole (Microtus arvalis). Mol Ecol 18:2518-2531. https://doi.org/10.1111/j.1365294X.2009.04189.x
Bray SCE, Austin JJ, Metcalf JL, Østbye K, Østbye E, Lauritzen SE, Aaris-Sørensen K, Valdiosera C, Adler CJ, Cooper A (2013) Ancient DNA identifies post-glacial recolonisation, not recent bottlenecks, as the primary driver of contemporary mtDNA phylogeography and diversity in Scandinavian brown bears. Divers Distrib 19:245-256. https://doi.org/10.1111/j.1472-4642. 2012.00923.x

Bulatova NS, Golenishchev FN, Koval'skaya YM, Emelyanova LG, Bystrakova NV, Pavlova SV, Nadzhafova RS, Lavrechenko LA (2010) Cytogenetic study of the parapatric contact zone between two 46-chromosomal forms of the common vole in European Russia. Russ J Genet 46: 443-448. Original Russian text: Bulatova NS, Golenishchev FN, Koval'skaya YM, Emelyanova LG, Bystrakova NV, Pavlova SV, Nadzhafova RS, Lavrechenko LA (2010) Genetika 46: 502-508. https://doi.org/10.1134/ S1022795410040095

Charlier J, Laikre L, Ryman N (2008) Genetic structure and evidence of a local bottleneck in moose in Sweden. J Wildl Manag 72:411-415. https://doi.org/10.2193/2007-122

Cheddadi R, Bar-Hen A (2008) Spatial gradient of temperature and potential vegetation feedback across Europe during the late Quaternary. Clim Dyn 32:371-379. https://doi.org/10.1007/ s00382-008-0405-7

Clark PU, Dyke AS, Shakun JD, Carlson AE, Clark J, Wohlfarth B, Mitrovica JX, Hostetler SW, McCabe AM (2009) The last glacial maximum. Science 325:710-714. https://doi.org/10.1126/science. 1172873

Colangelo P, Bannikova AA, Kryštufek B, Lebedev VS, Annesi F, Capanna E, Loy A (2010) Molecular systematic and evolutionary biogeography of the genus Talpa (Soricomorpha: Talpidae). Mol Phylogenet Evol 55:372-380. https://doi.org/10.1016/j.ympev. 2010.01.038

Cox CB, Moore PD (1993) Biogeography an ecological and evolutionary approach, Fifth edn. Blackwell Scientific Publications, Oxford

Czarnomska DS, Jędrzejewska B, Borowik T, Niedziałkowska M, Stronen AV, Nowak S, Mysłajek RW, Okarma H, Konopiński M, Pilot M, Śmietana W, Caniglia R, Fabbri E, Randi E, Pertoldi C, Jędrzejewski W (2013) Concordant mitochondrial and microsatellite DNA structuring between Polish lowland and Carpathian Mountain wolves. Conserv Genet 14:573-588. https://doi.org/10. 1111/mam.12052

Davison A, Birks JS, Brookes RC, Messenger JE, Griffiths HI (2001) Mitochondrial phylogeography and population history of pine martens Martes martes compared with polecats Mustela putorius. Mol Ecol 10:2479-2488. https://doi.org/10.1046/j.1365-294X.2001. 01381.x

Davison J, Ho SYW, Bray SC, Korsten M, Tammeleht E, Hindrikson M, Østbye K, Østbye E, Lauritzen SE, Austin J, Cooper A, Saarma U (2011) Late-Quaternary biogeographic scenarios for the brown bear (Ursus arctos), a wild mammal model species. Quat Sci Rev 30: 418-430. https://doi.org/10.1016/j.quascirev.2010.11.023

Deffontaine V, Libois R, Kotlík P, Sommer R, Nieberding C, Paradis E, Searle JB, Michaux JR (2005) Beyond the Mediterranean peninsulas: evidence of central European glacial refugia for a temperate forest mammal species, the bank vole (Clethrionomys glareolus). Mol Ecol 14:1727-1739. https://doi.org/10.1111/j.1365-294X. 2005.02506.x

Dingerkus SK, Montgomery WI (2001) The diet and land class affinities of the Irish hare (Lepus timidus hibernicus) in Northern Ireland. Mammal Rev 32:1-11. https://doi.org/10.1017/S0952836901000206

Dool SE, Puechmaille SJ, Dietz C, Juste J, Ibáñez C, Hulva P, Roué SG, Petit EJ, Jones G, Russo D, Toffoli R, Viglino A, Martinoli A, Rossiter SJ, Teeling EC (2013) Phylogeography and postglacial recolonization of Europe by Rhinolophus hipposideros: evidence from multiple genetic markers. Mol Ecol 22:4055-4070. https:// doi.org/10.1111/mec. 12373 
Edwards CJ, Soulsbury CD, Statham MJ, Ho SYW, Wall D, Dolf G, Iossa G, Baker PJ, Harris S, Sacks BN, Bradley DG (2012) Temporal genetic variation of the red fox, Vulpes vulpes, across western Europe and the British Isles. Quat Sci Rev 57:95-104. https://doi. org/10.1016/j.quascirev.2012.10.010

Filipi K, Marková S, Searle JB, Kotlík P (2015) Mitogenomic phylogenetics of the bank vole Clethrionomys glareolus, a model system for studying end-glacial colonization of Europe. Mol Phylogenet Evol 82:245-257. https://doi.org/10.1016/j.ympev.2014.10.016

Frantz AC, McDevitt AD, Pope LC, Kochan J, Davison J, Clements CF, Elmeros M, Molina-Vacas G, Ruiz-Gonzalez A, Balestrieri A, Van Den Berge K, Breyne P, Do Linh San E, Ågren EO, Suchentrunk F, Schley L, Kowalczyk R, Kostka BI, Ćirović D, Šprem N, Colyn M, Ghirardi M, Racheva V, Braun C, Oliveira R, Lanszki J, Stubbe A, Stubbe M, Stier N, Burke T (2014) Revisiting the phylogeography and demography of European badgers (Meles meles) based on broad sampling, multiple markers and simulations. Heredity 113:443-453. https://doi.org/10.1038/hdy.2014.45

Gębczyńska Z, Raczyński J (2004) Moose in the Biebrza River valley. In: The situation of moose populations in Poland. Biebrza National Park Press, Osowiec, pp 5-19 [in Polish]

Gleiss HGW (1967) Unter Robben, Gnus und Tigerschlangen. Chronik des Zoologischen Gartens Breslau 1865-1965. Natura et Patria Verlag, Wedel

Gula R (2004) Influence of snow cover on wolf predation patterns in Bieszczady Mountains, Poland. Wildl Biol 10:17-23. https://doi. org/10.2981/wlb.2004.005

Gula R (2008) Legal protection of wolves in Poland: implications for the status of the wolf population. Eur J Wildl Res 54:163-170. https:// doi.org/10.1007/s10531-009-9581-y

Haynes S, Jaarola M, Searle JB (2003) Phylogeography of the common vole Microtus arvalis with particular emphasis on the colonization of the Orkney archipelago. Mol Ecol 12:951-956. https://doi.org/10. 1046/j.1365-294X.2003.01795.x

Heckel G, Burri R, Fink S, Desmet JF, Excoffier L (2005) Genetic structure and colonization processes in European populations of the common vole Microtus arvalis. Evolution 59:2231-2242. https://doi. org/10.1111/j.0014-3820.2005.tb00931.x

Herman JS, Searle JB (2011) Post-glacial partitioning of mitochondrial genetic variation in the field vole. Proc R Soc B 278:3601-3607. https://doi.org/10.1098/rspb.2011.0321

Herman JS, McDevitt AD, Kawałko A, Jaarola M, Wójcik JM, Searle JB (2014) Land-bridge calibration of molecular clocks and the postglacial colonization of Scandinavia by the Eurasian field vole Microtus agrestis. PLoS One 9:e103949. https://doi.org/10.1371/journal. pone. 0103949

Herman JS, Stojak J, Paupério J, Jaarola M, Wójcik JM, Searle JB (2019) Genetic variation in field voles Microtus agrestis from the British Isles: selective sweeps or population bottlenecks. Biol J Linn Soc 126:852-865. https://doi.org/10.1093/biolinnean/bly213

Herrera JP (2017) The effects of biogeography and biotic interactions on lemur community assembly. Int J Primatol 38:692-716. https://doi. org/10.1007/s10764-017-9974-9

Hewitt GM (1999) Post-glacial re-colonization of European biota. Biol J Linn Soc 68:87-112. https://doi.org/10.1006/bijl.1999.0332

Hijmans RJ, Cameron SE, Parra JL, Jones PG, Jarvis A (2005) Very high resolution interpolated climate surfaces for global land areas. Int J Climatol 25:1965-1978. https://doi.org/10.1002/joc.1276

Horáček I, Ložek V, Knitlová M, Juřičkova L (2015) Darkness under candlestick: glacial refugia on mountain glaciers. In: Sálezova $\mathrm{S}$, Novák M, Mizerová A (eds) Forgotten times and spaces: new perspectives in paleoanthropological, paleoetnological and archeological studies, 1st edn. Institute of Archaeology of the Czech Academy of Sciences and Masaryk University, Brno, pp 363-377
Horreo JL, Pelaez ML, Suárez T, Breedveld MC, Heulin B, Surget-Groba Y, Oksanen TA, Fitze PS (2018) Phylogeography, evolutionary history and effects of glaciations in a species (Zootoca vivipara) inhabiting multiple biogeographic regions. J Biogeogr 45:16161627. https://doi.org/10.1111/jbi.13349

Huck M, Jędrzejewski W, Borowik T, Miłosz-Cielma M, Schmidt K, Jędrzejewska B, Nowak S, Mysłajek RW (2010) Habitat suitability, corridors and dispersal barriers for large carnivores in Poland. Acta Theriol 55:177-192. https://doi.org/10.4098/j.at.0001-7051.114. 2009

Hughes PD, Gibbard PL, Ehlers J (2013) Timing of glaciation during the last glacial cycle: evaluating the concept of a global 'Last Glacial Maximum' (LGM). Earth Sci Rev 125:171-198. https://doi.org/10. 1016/j.earscirev.2013.07.003

Jaarola M, Searle JB (2002) Phylogeography of field voles (Microtus agrestis) in Eurasia inferred from mitochondrial DNA sequences. Mol Ecol 11:2613-2621. https://doi.org/10.1046/j.1365-294X. 2002.01639.x

Jędrzejewska B, Jędrzejewski W, Bunevich AN, Miłkowski L, Okarma H (1996) Population dynamics of wolves Canis lupus in Białowieża Primeval Forest (Poland and Belarus) in relation to hunting by humans, 1847-1993. Mammal Rev 26:103-126. https://doi.org/10. 1111/j.1365-2907.1996.tb00149.x

Jędrzejewski W, Niedziałkowska M, Hayward MW, Goszczyński J, Jędrzejewska B, Borowik T, Bartoń KA, Nowak S, Harmuszkiewicz J, Juszczyk A, Kałamarz T, Kloch A, Koniuch J, Kotiuk K, Mysłajek RW, Nędzyńska M, Olczyk A, Teleon M, Wojtulewicz M (2012) Prey choice and diet of wolves related to ungulate communities and wolf subpopulations in Poland. J Mammal 93:1480-1492. https://doi.org/10.1644/10-MAMM-A132.1

Jones EP, Searle JB (2015) Differing Y chromosome versus mitochondrial DNA ancestry, phylogeography, and introgression in the house mouse. Biol J Linn Soc 115:348-361. https://doi.org/10.1111/bij. 12522

Kinoshita E, Kosintsev PA, Raichev EG, Haukisalmi VK, Kryukov AP, Wiig Ø, Abramov AV, Kaneko Y, Masuda R (2017) Molecular phylogeny of Eurasian badgers (Meles) around the distribution boundaries, revealed by analyses of mitochondrial DNA and Ychromosomal genes. Biochem Syst Ecol 71:121-130. https://doi. org/10.1016/j.bse.2017.01.011

Kotlík P, Deffontaine V, Mascheretti S, Zima J, Michaux JR, Searle JB (2006) A northern glacial refugium for bank voles Clethrionomys glareolus. Proc Natl Acad Sci U S A 103:14860-14864. https://doi. org/10.1073/pnas.0603237103

Kotlík P, Marková S, Konczal M, Babik W, Searle JB (2018) Genomics of end-Pleistocene population replacement in a small mammal. Proc R Soc B 285:20172624. https://doi.org/10.1098/rspb.2017.2624

Kusza S, Podgórski T, Scandura M, Borowik T, Jávor A, Sidorovich VE, Bunevich AN, Kolesnikov M, Jędrzejewska B (2014) Contemporary genetic structure, phylogeography and past demographic processes of wild boar Sus scrofa population in central and eastern Europe. PLoS One 9(3):e91401. https://doi.org/10. 1371/journal.pone.0091401

Kvist L, Viiri K, Dias PC, Rytkönen S, Orell M (2004) Glacial history and colonization of Europe by the blue tit Parus caeruleus. J Avian Biol 35:352-359. https://doi.org/10.1111/j.0908-8857.2004.03297.x

Lagerholm VK, Sandoval-Castellanos E, Ehrich D, Abramson NI, Nadachowski A, Kalthoff DC, Germonpré M, Angerbjörn A, Stewart JR, Dalén J (2014) On the origin of the Norwegian lemming. Mol Ecol 23:2060-2071. https://doi.org/10.1111/mec.12698

Lebarbenchon C, Poitevin F, Arnal V, Montgelard C (2010) Phylogeography of the weasel (Mustela nivalis) in the westernPalaearctic region: combined effects of glacial events and human movements. Heredity 105:449-462. https://doi.org/10.1038/hdy. 2009.186 
Lozinski W (1909) On the mechanical weathering of sandstones in temperate climates. In: Evans DJ (ed) 1994, Cold Climate Landforms. Wiley, Chichester, pp 119-134

Marks L, Gałązka D, Woronko B (2016) Climate, environment and stratigraphy of the last Pleistocene glacial stage in Poland. Quat Int 420: 259-271

Martínková N, Barnett R, Cucchi T, Struchen R, Pascal M, Pascal M, Fischer MC, Higham T, Brace S, Ho SY, Quéré JP, O'Higgins P, Excoffier L, Heckel G, Hoelzel AR, Dobney KM, Searle JB (2013) Divergent evolutionary processes associated with colonization of offshore islands. Mol Ecol 22:5205-5220. https://doi.org/10.1111/ mec. 12462

Matosiuk M, Sheremetyeva IN, Sheremetyev IS, Saveljev AP, Borkowska A (2014a) Evolutionary neutrality of mtDNA introgression: evidence from complete mitogenome analysis in roe deer. $\mathrm{J}$ Evol Biol 27:2483-2494. https://doi.org/10.1111/jeb.12491

Matosiuk M, Borkowska A, Świsłocka M, Mirski P, Borowski Z, Krysiuk K, Danilkin AA, Zvychaynaya EY, Saveljev AP, Ratkiewicz M (2014b) Unexpected population genetic structure of European roe deer in Poland: an invasion of the mtDNA genome from Siberian roe deer. Mol Ecol 23:2559-2572. https://doi.org/10.1111/mec.12745

McDevitt AD, Zub K, Kawałko A, Oliver MK, Herman JS, Wójcik JM (2012) Climate and refugial origin influence the mitochondrial lineage distribution of weasels Mustela nivalis in a phylogeographic suture zone. Biol J Linn Soc 106:57-69. https://doi.org/10.1111/j. 1095-8312.2012.01840.x

Meiri M, Lister AM, Higham TF, Stewart JR, Straus LG, Obermaier H, González Morales MR, Marín-Arroyo AB, Barnes I (2013) Lateglacial recolonization and phylogeography of European red deer (Cervus elaphus L.). Mol Ecol 22:4711-4722. https://doi.org/10. $1111 /$ mec. 12420

Michaux JR, Magnanou E, Paradis E, Nieberding C, Libois R (2003) Mitochondrial phylogeography of the wood mouse (Apodemus sylvaticus) in the Western Palaearctic region. Mol Ecol 12:685697. https://doi.org/10.1046/j.1365-294X.2003.01752.x

Montgomery WI, Provan J, McCabe AM, Yalden DW (2014) Origin of British and Irish mammals: disparate post-glacial colonisation and species introductions. Quat Sci Rev 98:144-165. https://doi.org/10. 1016/j.quascirev.2014.05.026

Murphy JC, Sierra TA, Downie JR, Jowers MJ (2017) Toads, tall mountains and taxonomy: the Rhinella granulosa group (Amphibia: Anura: Bufonidae) on both sides of the Andes. Salamandra 53: 267-278

Nadachowski A (1989) Origin and history of the present rodent fauna in Poland based on fossil evidence. Acta Theriol 34:37-53. https://doi. org/10.4098/AT.arch.89-2

Nadachowski A (1990) Review of fossil Rodentia from Poland (Mammalia). Senckenberg Biol 70(4/6):229-250

Nadachowski A, Valde-Nowak P (2015) New Late Pleistocene faunal assemblages from Podhale Basin, western Carpathians, Poland: preliminary results. Acta Zool Cracov 58(2):181-194

Nadachowski A, Harrison DL, Szyndlar Z, Tomek T, Wolsan M (1993) Late Pleistocene vertebrate fauna from Obłazowa 2 (Carpathians, Poland): paleoecological reconstruction. Acta Zool Cracov 36(2): 281-290

Nadachowski A, Żarski M, Urbanowski M, Wojtal P, Miękina B, Lipecki G, Ochman K, Krawczyk M, Jakubowski G, Tomek T (2009) Late Pleistocene environment of the Częstochowa Upland (Poland) reconstructed on the basis of faunistic evidence from archaeological cave sites. Institute of Systematics and Evolution of Animals, Polish Academy of Sciences, Kraków, p 112

Neumann K, Michaux R, Maak S, Jansmann AH, Kayser A, Mundt G, Gattermann R (2005) Genetic spatial structure of European common hamsters (Cricetus cricetus) - a result of repeated range expansion and demographic bottlenecks. Mol Ecol 14:1473-1483. https://doi. org/10.1111/j.1365-294X.2005.02519.x
Niedziałkowska M, Jędrzejewska B, Honnen AC, Otto T, Sidorovich VE, Perzanowski K, Skog A, Hartl GB, Borowik T, Bunevich AN, Lang J, Zachos FE (2011) Molecular biogeography of red deer Cervus elaphus from eastern Europe: insights from mitochondrial DNA sequences. Acta Theriol 56:1-12. https://doi.org/10.1007/s13364010-0002-0

Niedziałkowska M, Jędrzejewska B, Wójcik JM, Goodman SJ (2012) Genetic structure of red deer population in northeastern Poland in relation to the history of human interventions. J Wildl Manag 76: 1264-1276. https://doi.org/10.1002/jwmg.367

Niedziałkowska M, Hundertmark KJ, Jędrzejewska B, Niedziałkowski K, Sidorovich VE, Górny M, Veeroja R, Solberg EJ, Laaksonen S, Sand H, Solovyev VA, Shkvyria M, Tiainen J, Okhlopkov IM, Juškaitis R, Done G, Borodulin VA, Tulandin EA, Jędrzejewski W (2014) Spatial structure in European moose (Alces alces): genetic data reveal a complex population history. J Biogeogr 41:2173-2184. https://doi.org/10.1111/jbi.12362

Niedziałkowska M, Jędrzejewska B, Danyłow J, Niedziałkowski K (2016) Diverse rates of gene flow and long-distance migration in two moose Alces alces subpopulations in Europe. Mammal Res 61: 171-178. https://doi.org/10.1007/s13364-016-0274-0

Olano-Marin J, Plis K, Sönnichsen L, Borowik T, Niedziałkowska M, Jędrzejewska B (2014) Weak population structure in European roe deer (Capreolus capreolus) and evidence of introgressive hybridization with Siberian roe deer (C. pygargus) in northeastern Poland. PLoS One 9(10): e10914. https://doi.org/10.1371/journal.pone. 0109147, e109147

Palmé AE, Su Q, Rautenberg A, Manni F, Lascoux M (2003) Postglacial recolonization and cpDNA variation of silver birch, Betula pendula. Mol Ecol 12:201-212. https://doi.org/10.1046/j.1365-294X.2003. 01724.x

Pavlov MP (1999) Akklimatizatsia okhotnich'e-promylovykh zverei i ptits v SSSR. Chast' 3. Kopytnye (Acclimation of game mammals and birds in the Soviet Union: part 3. Ungulates). Kirov: Russian research institute of game management and Fur farming. [in Russian]

Pazonyi P (2004) Mammalian ecosystem dynamics in the Carpathian Basin during the last 27000 years. Palaeogeogr Palaeoclimatol Palaeoecol 212:295-314

Pilot M, Jędrzejewski W, Branicki W, Sidorovich VE, Jędrzejewska B, Stachura K, Funk SM (2006) Ecological factors influence population genetic structure of European grey wolves. Mol Ecol 15:45334553. https://doi.org/10.1111/j.1365-294X.2006.03110.x

Pilot M, Branicki W, Jędrzejewski W, Goszczyński J, Jędrzejewska B, Dykyy I, Shkvyrya M, Tsingarska E (2010) Phylogeographic history of grey wolves in Europe. BMC Evol Biol 10:104. https://doi.org/ 10.1186/1471-2148-10-104

Podgórski T, Śmietanka K (2018) Do wild boar movements drive the spread of African swine fever? Transbound Emerg Dis 65:15881596. https://doi.org/10.1111/tbed.12910

Podgórski T, Apollonio M, Keuling O (2018) Contact rates in wild boar populations: implications for disease transmission. J Wildl Manag 82:1210-1218. https://doi.org/10.1002/jwmg.21480

Quinzin MC, Normand S, Dellicour S, Svenning JC, Mardulyn P (2017) Glacial survival of trophically linked boreal species in northern Europe. Proc R Soc B 284:20162799. https://doi.org/10.1098/rspb. 2016.2799

Randi E, Alves PC, Carranza J, Milosevic-Zlatanovic S, Sfougaris A, Mucci N (2004) Phylogeography of roe deer (Capreolus capreolus) populations: the effects of historical genetic subdivisions and recent nonequilibrium dynamics. Mol Ecol 13:3071-3083. https://doi.org/ 10.1111/j.1365-294X.2004.02279.x

Rasmussen SO, Bigler M, Blockley SP, Blunier T, Buchardt SL, Clausen HB, Cvijanovic I, Dahl-Jensen D, Johnsen SJ, Fischer H, Gkinid V, Guillevic M, Hoek WZ, Lowe JJ, Pedro JB, Popp T, Seierstad IK, Steffensen JP, Svensson AM, Vallelonga P, Vinther BM, Walker 
MJC, Wheatley JJ, Winstrup M (2014) A stratigraphic framework for abrupt climatic changes during the last Glacial period based on three synchronized Greenland ice-core records: refining and extending the INTIMATE event stratigraphy. Quat Sci Rev 106:14-28. https://doi.org/10.1016/j.quascirev.2014.09.007

Raspopova AA, Bannikova AA., Lebedev VS (2018) The Phylogeography and demographic history of the common shrew Sorex araneus L., 1758 (Eulipotyphla, Mammalia). Russ J Genet 54: 1452-1465. Original Russian text: Raspopova AA, Bannikova AA, Lebedev VS (2018) Genetika 54: 1426-1441. https://doi.org/ 10.1111/zsc. 12302

Ratkiewicz M, Matosiuk M, Kowalczyk R, Konopiński MK, Okarma H, Ozolins J, Männil P, Ornicans A, Schmidt K (2012) High levels of population differentiation in Eurasian lynx at the edge of the species' western range in Europe revealed by mitochondrial DNA analyses. Anim Conserv 15:603-612. https://doi.org/10.1111/j.1469-1795. 2012.00556.x

Ratkiewicz M, Matosiuk M, Saveljev AP, Sidorovich V, Ozolins J, Männil P, Balciauskas L, Kojola I, Okarma H, Kowalczyk R, Schmidt K (2014) Long-range gene flow and the effects of climatic and ecological factors on genetic structuring in a large, solitary carnivore: the Eurasian lynx. PLoS One 9(12):e115160. https://doi.org/ 10.1371/journal.pone. 0115160

Remington CL (1968) Suture-zones of hybrid interaction between recently joined biota. In: Dobzhansky T, Hecht MK, Steere WC (eds) Evolutionary biology. Plenum Press, New York, pp 321-428

Ruiz-González A, José Madeira M, Randi E, Abramov AV, Davoli F, Gómez-Moliner BJ (2013) Phylogeography of the forest-dwelling European pine marten (Martes martes): new insights into cryptic northern glacial refugia. Biol J Linn Soc 109:1-18. https://doi.org/ 10.1111/bij. 12866

Saarma U, Ho SY, Pybus OG, Kaljuste M, Tumanov IL, Kojola I, Vorobiev AA, Markov NI, Saveljev AP, Valdmann H, Lyapunova EA, Abramov AV, Männil P, Korsten M, Vulla E, Pazetnov SV, Pazetnov VS, Putchkovskiy SV, Rõkov AM (2007) Mitogenetic structure of brown bears (Ursus arctos L.) in northeastern Europe and a new time frame for the formation of European brown bear lineages. Mol Ecol 16:401-413. https://doi.org/10.1111/j.1365294X.2006.03130.x

Schmidt K (2008) Behavioural and spatial adaptation of the Eurasian lynx to a decline in prey availability. Acta Theriol 53:1-16. https://doi. org/10.1007/BF03194274

Schmidt K, Ratkiewicz M, Konopiński M (2011) The importance of genetic variability and population differentiation in the Eurasian lynx Lynx lynx for conservation in the context of habitat and climate change. Mammal Rev 41:112-124. https://doi.org/10.1111/j.13652907.2010.00180.x

Schmitt T (2007) Molecular biogeography of Europe: Pleistocene cycles and postglacial trends. Front Zool 4:11. https://doi.org/10.1186/ 1742-9994-4-11

Schmölcke U, Zachos FE (2005) Holocene distribution and extinction of the moose (Alces alces, Cervidae) in Central Europe. Mamm Biol 70:329-344. https://doi.org/10.1016/j.mambio.2005.08.001

Searle JB, Kotlík P, Rambau RV, Marková S, Herman JS, McDevitt AD (2009) The Celtic fringe of Britain: insights from small mammal phylogeography. Proc Biol Sci 276:4287-4294

Sibiryakov PA, Tovpinets NN, Dupal TA, Semerikov VL, Yalkovskaya LE, Markova EA (2018) Phylogeography of the common vole Microtus arvalis, the obscurus form (Rodentia, Arvicolinae): new data on the mitochondrial DNA variability. Russ J Genet 54:11851198. Original Russian text: Sibiryakov PA, Tovpinets NN, Dupal TA, Semerikov VL, Yalkovskaya LE, Markova EA (2018) Genetika 54: 1162-1176. https://doi.org/10.1134/S1022795418100137

Skog A, Zachos FE, Rueness EK, Feulner PGD, Mysterud A, Langvatn R, Lorenzini R, Hmwe SS, Lehoczky I, Hartl GB, Stenseth NC, Jakobsen KS (2009) Phylogeography of red deer (Cervus elaphus) in Europe. J Biogeogr 36:66-77. https://doi.org/10.1111/j.13652699.2008.01986.x

Sommer RS, Nadachowski A (2006) Glacial refugia of mammals in Europe: evidence from fossil records. Mammal Rev 36:251-265. https://doi.org/10.1111/j.1365-2907.2006.00093.x

Starkel L (1991) Environmental changes at the younger Dryas Preboreal transition and during the early Holocene: some distinctive aspects in Central Europe. The Holocene 1:234-242. https://doi.org/ $10.1177 / 095968369100100305$

Starkel L (2001) Evolution of the Vistula river valley since the last glaciation till present. Warsaw: Polish Academy of Sciences Stanisław Leszczycki Institute of Geography and Spatial Organization. Monographies 2. [in Polish with English summary]

Steinbach HJ (2009) Moose survived in East Russia. Wild und Hund 17: $17-21$ in German

Stewart JR, Lister AM (2001) Cryptic northern refugia and the origins of the modern biota. Trends Ecol Evol 16:608-613. https://doi.org/10. 1016/S0169-5347(01)02338-2

Stewart JR, Lister AM, Barnes I, Dalén L (2010) Refugia revisited: individualistic responses of species in space and time. Proc Biol Sci 277: 661-671. https://doi.org/10.1098/rspb.2009.1272

Stojak J, McDevitt AD, Herman JS, Searle JB, Wójcik JM (2015) Postglacial colonization of eastern Europe from the Carpathian refugium: evidence from mitochondrial DNA of the common vole Microtus arvalis. Biol J Linn Soc 115:927-939. https://doi.org/10. 1111/bij.12535

Stojak J, McDevitt AD, Herman JS, Kryštufek B, Uhlíková J, Purger JJ, Lavrenchenko LA, Searle JB, Wójcik JM (2016a) Between the Balkans and the Baltic: phylogeography of a common vole mitochondrial DNA lineage limited to Central Europe. PLoS One 11(12):e0168621. https://doi.org/10.1371/journal.pone.0168621

Stojak J, Wójcik JM, Ruczyńska I, Searle JB, McDevitt AD (2016b) Contrasting and congruent patterns of genetic structuring in two Microtus vole species using museum specimens. Mammal Res 61: 141-152. https://doi.org/10.1007/s13364-018-0395-8

Stojak J, Borowik T, Górny M, McDevitt AD, Wójcik JM (2019) Climatic influences on the genetic structure and distribution of the common vole and field vole in Europe. Mammal Res 64:19-29. https://doi.org/10.1007/s13364-018-0395-8

Strandberg G, Brandefelt J, Kjellström E, Smith B (2011) High-resolution regional simulation of last glacial maximum climate in Europe. Tellus A 63:107-125. https://doi.org/10.1111/j.1600-0870.2010. 00485.X

Stroeven AP, Hättestrand C, Kleman J, Heyman J, Fabel D, Fredin O, Goodfellow BW, Harbor JM, Jansen JD, Olsen L, Caffee MW, Fink D, Lundqvist J, Rosqvist GC, Strömberg B, Jansson KN (2016) Deglaciation of Fennoscandia. Quat Sci Rev 147:91-121. https:// doi.org/10.1016/j.quascirev.2015.09.016

Świsłocka M, Ratkiewicz M, Borkowska A, Komenda E, Raczyński J (2008) Mitochondrial DNA diversity in moose, Alces alces from Northeastern Poland: evidence for admixture in bottlenecked relic population in the Biebrza valley. Ann Zool Fenn 45:360-365. https://doi.org/10.5735/086.045.0419

Świsłocka M, Czajkowska M, Duda N, Danylow J, Owadowska-Cornil E, Ratkiewicz M (2013) Complex patterns of population genetic structure of moose, Alces alces, after recent spatial expansion in Poland revealed by sex-linked markers. Acta Theriol 58:367-337. https://doi.org/10.1007/s13364-013-0148-7

Taberlet P, Fumagalli L, Wust-Saucy AG, Cosson JF (1998) Comparative phylogeography and postglacial colonization routes in Europe. Mol Ecol 7:453-464. https://doi.org/10.1046/j.1365-294x.1998.00289.x

Tarasov PE, Volkova VS, Webb T III, Guiot J, Andreev AA, Bezusko LG, Bezusko TV, Bykova GV, Dorofeyuk NI, Kvavadze EV, Osipova IM, Panova NK, Sevastyanov DV (2001) Last glacial maximum biomes reconstructed from pollen and plant macrofossil data from 
northern Eurasia. J Biogeogr 27:609-620. https://doi.org/10.1046/j. 1365-2699.2000.00429.x

Tarnowska E, Niedziałkowska M, Gerc J, Korbut Z, Górny M, Jędrzejewska B (2016) Spatial distribution of the Carpathian and eastern mtDNA lineages of the bank vole in their contact zone relates to environmental conditions. Biol J Linn Soc 119:732-744. https://doi.org/10.1111/bij.12764

Tarnowska E, Niedziałkowska M, Jędrzejewska B (2018) Genetic structure of bank vole population in the contact zone of two lineages in north-eastern Poland. Mamm Biol. https://doi.org/10.1016/j. mambio.2018.10.011

Tougard C, Montuire S, Volobouev V (2013) Exploring phylogeography and species limits in the Altai vole (Rodentia: Cricetidae). Biol J Linn Soc 108:434-452. https://doi.org/10.1111/j.1095-8312.2012. 02034.x

Trojan P (1997) The floristic and faunistic Korean refugium during the last glacial period and its significance in postglacial biota formation. Fragm Faun 40:215-221

Tzedakis PC, Emerson BC, Hewitt GM (2013) Cryptic or mystic? Glacial tree refugia in northern Europe. Trends Ecol Evol 28:696-704. https://doi.org/10.1016/j.tree.2013.09.001

Valde-Nowak P, Nadachowski A, Madeyska T (eds) (2003) Obłazowa Cave: human activity, stratigraphy and palaeoenvironment. Institute of Archaeology and Ethnology Polish Academy of Sciences, Kraków, p 176

Vilaça ST, Biosa D, Zachos F, Iacolina L, Kirschning J, Alves PC, Paule L, Gortazar C, Mamuris Z, Jędrzejewska B, Borowik T, Sidorovich VE, Kusak J, Costa S, Schley L, Hartl GB, Apollonio M, Bertorelle G, Scandura M (2014) Mitochondrial phylogeography of the European wild boar: the effect of climate on genetic diversity and spatial lineage sorting across Europe. J Biogeogr 41:987-998. https://doi.org/10.1111/jbi.12268

Warren RD, Waters DA, Altringham JD, Bullock DJ (2000) The distribution of Daubenton's bats (Myotis daubentonii) and pipistrelle bats
(Pipistrellus pipistrellus) (Vespertilionidae) in relation to small-scale variation in riverine habitat. Biol Conserv 92:85-91. https://doi.org/ 10.1016/S0006-3207(99)00062-2

Wielstra B, Zieliński P, Babik W (2017) The Carpathians hosted extraMediterranean refugia-within-refugia during the Pleistocene Ice Age: genomic evidence from two newt genera. Biol J Linn Soc 122:605-613. https://doi.org/10.1093/biolinnean/blx087

Wójcik JM, Kawałko A, Marková S, Searle JB, Kotlík P (2010) Phylogeographic signatures of northward post-glacial colonization from high-latitude refugia: a case study of bank voles using museum specimens. J Zool 281:249-262. https://doi.org/10.1111/j.14697998.2010.00699.x

Wysota W, Lankauf KR, Szmańda J, Chruścińska A, Oczkowski HL, Przegiętka KR (2002) Chronology of the Vistulian (Weichselian) glacial events in the lower Vistula region, middle-north Poland. Geochronometria 21:137-142

Wysota W, Molewski P, Sokołowski RJ (2009) Record of the Vistula ice lobe advances in the Late Weichselian glacial sequence in northCentral Poland. Quat Int 207:26-41. https://doi.org/10.1016/j. quaint.2008.12.015

Zasadni J, Kłapyta P (2014) The Tatra Mountains during the Last Glacial Maximum. J Maps 10(3):440-456

Zhigileva ON, Gorbacheva EV (2017) Distribution and parameters of genetic polymorphism in northern red-backed vole (Clethrionomys rutilus) and bank vole (Clethrionomys glareolus) in West Siberia. Contemp Probl Ecol 10:1-8. Original Russian text: Zhigileva ON, Gorbacheva EV (2017) Sibirskii Ekologicheskii Zhurnal 1: 3-11. https://doi.org/10.1134/S1995425517010139

Publisher's note Springer Nature remains neutral with regard to jurisdictional claims in published maps and institutional affiliations. 